\title{
Growth Performances and Growing Stock of Rattan in the Community Managed Forests of Nepal Chhote Lal Chowdhary ${ }^{1}$ and I.C. Dutta ${ }^{2}$
}

${ }^{1} \mathrm{PhD}$ Scholar, Mewar University, Rajasthan, India

${ }^{2}$ Professor, Tribhuvan University, Kirtipur, Nepal

\section{Corresponding Author}

Chhote Lal Chowdhary

Email: clchowdhary2006@gmail.com

\section{ABSTRACT}

Calamus tenuis Roxb, the economically potential rattan species, has been increasing in the community managed forests. Quantitative and qualitative information was collected in 2016 and 2017. The research was carried out in 20 Community Forest User Groups of Kailali and Bardiya district. Growing stock was measured using stratified random sampling in the community forests, followed by socio-economic information through semi-structured questionnaire to 526 respondentsincluding focus group discussions with executive member of community forest user groups. The study found that average growth of Calamus tenuis in the community forests was $0.85 \mathrm{cms}$ per year, the maximum growth attained up to 2.5 meter per year if they get associated trees to climb on. It' is a clumpy palm, producing 3-7 rhizomes in one year and reaches up to 25 rhizomes in 3-4 years period. There are 15 to 25 percent immature culms in a clump with estimate the number of clumps per hectare in managed rattan forest are 200 to 500 . Growing stock is estimated from 38,860 to 39,560 per hectare in the community forest comprising about 57 percent large size, 19 percent medium size and 24percent regeneration. The mean length was measured 5.80 meter and mean diameter $9.29 \mathrm{~mm}$. Weight difference of rattan with and without leaf sheath is 25 percent, reduction in oven dry weight is 75.9 percent, and air dry weight is 32 percent. More than 20 CFUGs have produced natural rattan in the community forests of Kailali and Bardiya districts. By the number of CFUGs, Bardiya district has more than 19 CFUGs and Kailali district has one CFUG managing natural rattan. Total estimated production of rattan in both districts is over 250 metric ton. Harvesting is restricted due to limitation of provision of Initial Environment Examination (IEE). According to these conditions, CFUGs should have get approval the detail IEE. None of the CFUGS have prepared the IEE. In such a condition, CFUGs can only harvest less than five quintal $(5000 \mathrm{~kg}$ ) rattan as per approved FOP. The study concludes that despite site quality remains constant, the associated tree species to climb them are encouraging factor. Detail growing stock needs to be incorporated in the rattan management plan / forest operational plan to mainstream in the process. 


\section{KEYWORDS}

Annual increment, Dry weight, Growth, Growing stock, Inventory, Linear length, Management method

\section{INTRODUCTION}

Calamus tenuis Roxb is economically potential Non-Timber Forest Products (NTFPs) in Nepal, distributed in tropical forest an altitudinal range from 75 to 500 meter. It belongs to Lepidocaryoidae, a large group of the palm family. Calamus tenuis Roxb, has protected mostly in community forests (Chowdhary \& Paudel, 2008). About 90 percent of the production of cane comes from natural forests and the rest from plantations being raised by most of the major producing countries (Iqbal, 1993; Manokaran, 1990; Pabuayon, 2000; Sastry, 2002). Despite its immense commercial significance, rattan faces difficulties and uncertainties inherent in ascertaining sustainable extraction level and impacts associated with harvesting (Siebert, 2002).

Rattan is collected almost exclusively from wild population and market demand for rattan cane is strong (Dransfield \& Manokaran, 1993) and the majority is gathered from forests in which management has been largely absent or ineffective Barry et al (2003).Calamus tenuis including other NTFPs are planted for commercial purposes (K.Sengdala \& Evans, 2002). The study carried out in Bangladesh shows that the maximum stem length of Calamus tenuiswas recorded 21.15m (Islam S. A., Miah, Habib, \& Rasul, 2015). According to research studies and observation carried out in the Philippines the cane grows at the average rate of 0.70 meter per year (IIRR, 1992). A similar study carried out in China by Yang et al (ND) also showed that some medium-diameter species, such as Daemonorops margarita and Calamus simplicifolius, growing fast with annual increment of 1.0-1.5 $\mathrm{m}$ and continue to keep these vigorous trends for 2 to 3 years or more after reaching technical maturation. Sunderland and Drandfield (2000)reported that rattans are vigorous climbers with relatively high growth rate. Sukla (2015)also concluded that growth of Calamus tenuis in Meerut areas was $1.95 \mathrm{~m}$.

Calamus tenuisis a clumpy palm. It produces 3-7 rhizomes in one year and increase up to 25 rhizomes in 3-4 years period. There are 15 to 25 percent immature culms in a clump with estimate the number of clumps per hectare in managed rattan forest are 200 to 500. Growing stock was estimated from 38,860 to 39,560 per hectare in the community managed forest comprising about 57 percent large size, 19percent medium size and about 24 percent regeneration. The mean length was measured 5.80 meter and mean diameter $9.29 \mathrm{~mm}$.

Growth performance of Calamus tenuis in community forests of Sati Community Forest of Kailali, Shiva Community Forest and Sarswoti Community Forest of Bardiya districts are 1.28 meter, 0.63 meter and 0.65 meter, respectively. Average growth of Calamus tenuis in community forests was 0.85 meter per year, the maximum growth attained up to 2.5 meter per year if they get associated trees to climb on. Weight of rattan varied with leaf sheath, oven dry weight, and air dry weight. Total estimated production of rattan in both districts is over 250 metric ton. However, more CFUGs are waiting for Initial Environment Examination (IEE) report to overcome this restriction. 
ISSN: 2362-1303 (Paper) | eISSN: 2362-1311 (Online)

JOURNAL OF ADVANCED ACADEMIC RESEARCH (JAAR)

\section{METHODOLOGY}

The study was carried out in the community forests of Kailali and Bardiya districts. Sampling size was determined from the total availability of rattan in community forests. Sampling design was ascertained based on certain criterions such as community forestry user groups leading to manage rattan, handed over community forest, harvested rattan in the previous years, and approved Forest Operational Plan (FOP). By number of forest, out of 20 community forests having rattan available, 10 community forests were sampled. The study was based on the study conducted in community forest user groups (CFUG) of Kailali and Bardiya districts which are located in the far and mid-west Terai of Nepal, there was 10 to 15 number of sampling plots selected for pilot sampling. The questionnaire survey was conducted to 526 respondents in 10 Community Forest User Group members to access socio-economic and management information. Sampling size were selected using Yamane formula (for finite population), the confidence level for this purpose is $95 \%$ at $\mathrm{p}=0.05$. Quantitative data of the growing stock was collected using stratified random sampling in $10 \mathrm{~m}$ x10 m sampling plot, oven dry weight was measured in laboratory of Department of Forest Research and Survey, air dry weight was measured in the field. Current Annual Increment (CAI) and Mean Annual Increment (MAI) was estimated referring growth of stem in a periodic time interval and MAI with the average mean annual increment using (Chapman, 1921). MAI was calculated using (Husch, Miller, \& Beers, 1982). The length and diameter of stems was taken above $15.24 \mathrm{~cm}$ from the ground level. The quantitative data was analyzed using SPSS 20 and Microsoft Excel analysis software tools. Qualitative data was analyzed using descriptive method and narratives were presented in relevant to contents. 
ISSN: 2362-1303 (Paper) | eISSN: 2362-1311 (Online)

JOURNAL OF ADVANCED ACADEMIC RESEARCH (JAAR)

June 2020

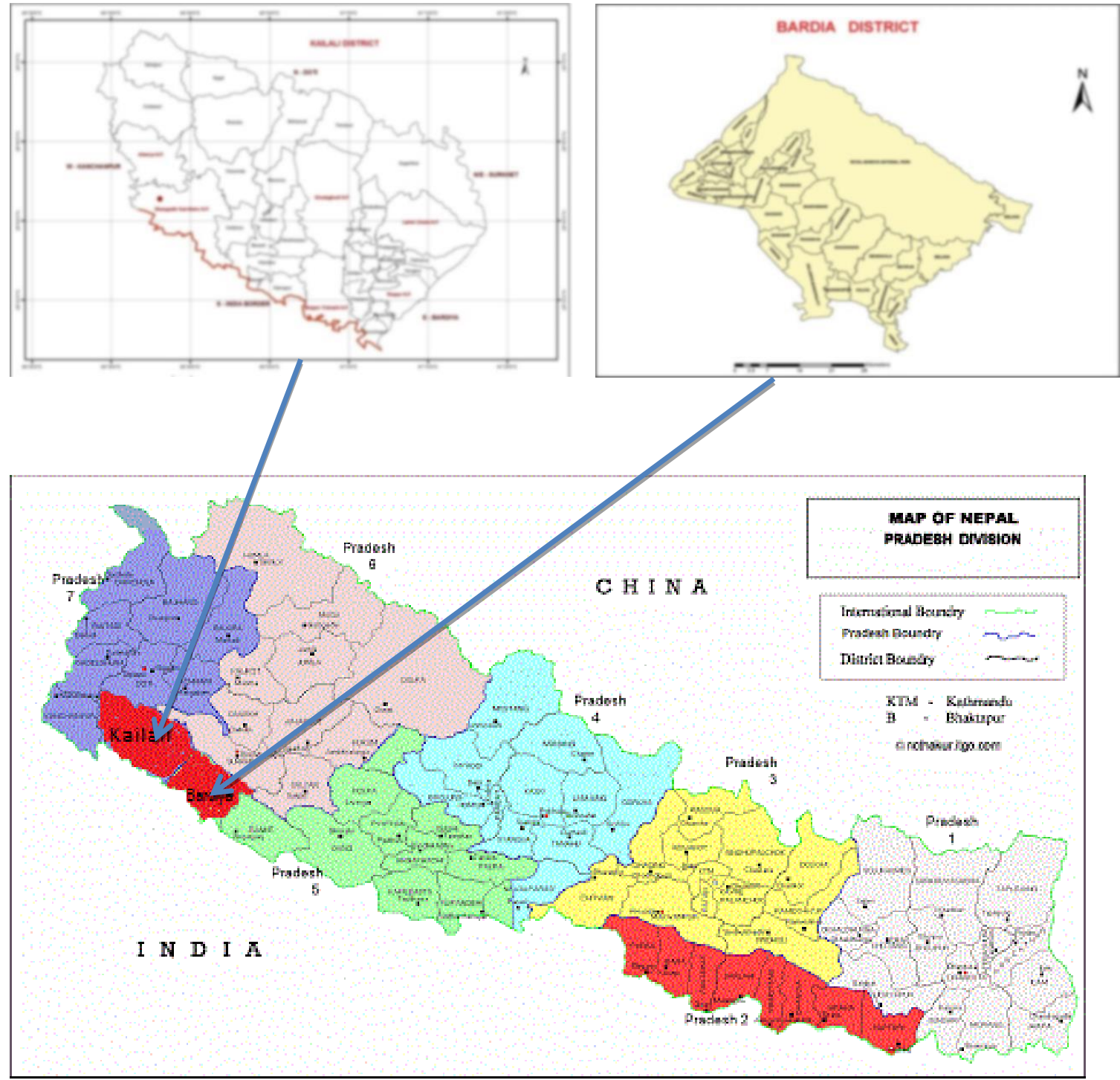

Figure 1: Map of study area- Kailali and Bardiya district

\section{RESULTS}

\section{Development of seedling}

A study on germination and growth of seeding was carried out in rattan. For this experiment, 100 seeds of Calamus acanthospathus and 48 seeds of Calamus leptospadix were tested in two nurseries - Sati Karnali Community Forest of Kailali (165 meter) and Salyan (1550 meter). Kailali has tropical climate whereas Salyan has sub-tropical climate. Seeds were collected from Asam India. It was sown in the nursery after 20 days of seed collection. The combined result showed the $75.7 \%$ germination (Table 1). 
ISSN: 2362-1303 (Paper) | eISSN: 2362-1311 (Online)

JOURNAL OF ADVANCED ACADEMIC RESEARCH (JAAR)

Table 1: Germination and growth of rattan seedling

\begin{tabular}{|l|l|l|l|}
\hline Number of days & $\begin{array}{l}\text { Number of seeds } \\
\text { germinated }\end{array}$ & $\%$ & Average Height $(\mathrm{cm})$ \\
\hline 75 & 81 & 54.7 & 3.7 \\
\hline 91 & 98 & 66.2 & 4.5 \\
\hline 107 & 104 & 70.7 & 5.9 \\
\hline 123 & 112 & 75.7 & 8.4 \\
\hline
\end{tabular}

Maximum germination was occurred between 60 to 80 days, and continued up to 117 days. Germination was 100 percent in Calamus acanthospathus and 64 percent in Calamus leptospadix. Similarly, survival percent was studied in the community nursery of Sati Karnali Community Forest User Group, Kailali. Seeds of Calamus tenuis was taken 2100, Calamus latifolius 150 and Calamus acanthospathus 350. Calamus tenuis was collected from local Community Forests, Calamus latifolius and Calamus acanthospathus was brought from Asam India (Table 2).

Table 2: Comparative survival of seedling (in percent)

\begin{tabular}{|l|l|l|l|l|l|l|}
\hline \multirow{2}{*}{ Month } & \multicolumn{2}{|l|}{ Calamus tenuis } & \multicolumn{2}{l|}{ Calamuslatifolius } & \multicolumn{2}{l|}{ Calamus acanthospathus } \\
\cline { 2 - 7 } & $\begin{array}{l}\text { Numberof } \\
\text { seedling }\end{array}$ & $\begin{array}{l}\text { Survival } \\
\text { percent }\end{array}$ & $\begin{array}{l}\text { Number of } \\
\text { seedling }\end{array}$ & $\begin{array}{l}\text { Survival } \\
\text { percent }\end{array}$ & $\begin{array}{l}\text { Number of } \\
\text { seedling }\end{array}$ & $\begin{array}{l}\text { Survival } \\
\text { percent }\end{array}$ \\
\hline 4 & 2100 & 84.3 & 150 & 36.8 & 350 & 58.3 \\
\hline 5 & 1500 & 60. & 135 & 33.1 & 197 & 32.8 \\
\hline
\end{tabular}

The combined performance of all the three species was 30.2 percent after 60 days, whereas species wise result shows that Calamus tenuis 40.2 per cent, Calamus acanthospathus 20.4 per cent and Calamus latifolius 30 per cent germination. Seed germination was taken place from 21 days. Survival percent of seedling was recorded in $4^{\text {th }}$ and $5^{\text {th }}$ month. The result shows that survival percent was higher in Calamuss tenuis up to $4^{\text {th }}$ month in Kailali and then decreased, whereas less in Calamus acanthospathus.

\section{Growth of rattan}

Average growth performance of Calamus tenuisin community forests is 0.85 meter per year. However, specific to community forest of Sati Karnali Community Forest of Kailali, Shiva Community Forest and Sarswoti Community Forest of Bardiya districts are 1.28 meter, 0.63 meter and 0.65 meter per year, respectively, and maximum growth was recorded 2.5 meter per year particularly when they were supported by trees to climb on them.

\section{Growing stock}

Calamus tenuis is a clumpy palm. It produces 3-7 rhizomes in one year and increase up to 2 rhizomes in 3-4 years period. Clumps are heterogeneous in natural condition. Distance between clumps to clump is $0.58 \mathrm{~m}$ to $2.06 \mathrm{~m}$. There are 15 to 25 percent immature culms in a clump. Number of clumps per hectare in the managed rattan forest has 200 to 500 . 
ISSN: 2362-1303 (Paper) | eISSN: 2362-1311 (Online)

JOURNAL OF ADVANCED ACADEMIC RESEARCH (JAAR)

June 2020

Average number of rattan cane in Sati Karnali Community Forest of Kailali, Shiva Community Forests and Sarswoti Community Forests of Bardiya were found 4 in per square meter. Mean diameter is $9.28 \mathrm{~mm}$. specifically; mean diameter of Shiva, Sati Karnali and Sarswoti community forests is $9.39 \mathrm{~mm}, 8.77 \mathrm{~mm}$ and $9.7 \mathrm{~mm}$ (Table 3). The estimation shows that there are no more differences in growing stock in per square meter in them.

Table 3: Growing stock of rattan in Sati Karnali, Shiva and Sarswoti Community Forests

\begin{tabular}{|l|l|l|l|}
\hline Parameters & Shiva & Sati & Sarswoti \\
\hline Area of plot $\left(\mathrm{m}^{2}\right)$ & 1000 & 1000 & 1000 \\
\hline No of large cane & 2200 & 2044 & 2256 \\
\hline No of medium cane & 554 & 967 & 528 \\
\hline No of small cane & 866 & 945 & 854 \\
\hline Av no/ m2 & 3.886 & 3.956 & 3.892 \\
\hline Av no/ ha & 38860 & 39560 & 38920 \\
\hline Total length m. (100 samples) & 585.15 & 547.00 & 668.00 \\
\hline Mean & 22.19 & 18.6 & 22.71 \\
\hline Diameter & 939 & 877 & 970 \\
\hline Mean & 9.39 & 8.77 & 9.7 \\
\hline
\end{tabular}

Field survey 2016

\section{Stem length, minimum and maximum diameter and standard error}

The stem length, minimum and maximum diameter and standard error of rattan in Sati Karnali Community Forest shows that average length of rattan cane in six years period was 6.4 meter, where minimum and maximum length were 3.9 meter and 8.3 meter, and average minimum and maximum diameter over leaf sheath were $3.4 \mathrm{~cm}$ and $4.4 \mathrm{~cm}$ (average diameter $3.9 \mathrm{~cm}$ ). The measurement of length and diameter of culms in plot 1 to 8 is presented in Table 4 and 5 . The community forest was divided into 8 plots for management purpose. 
ISSN: 2362-1303 (Paper) | eISSN: 2362-1311 (Online)

JOURNAL OF ADVANCED ACADEMIC RESEARCH (JAAR)

Table 4: Average lengths, minimum and maximum length and standard error

\begin{tabular}{|l|l|l|l|l|}
\hline Plots no & $\begin{array}{l}\text { Average length } \\
(\mathrm{m})\end{array}$ & Standard error & $\begin{array}{l}\text { Minimum length } \\
(\mathrm{m})\end{array}$ & $\begin{array}{l}\text { Maximum length } \\
(\mathrm{m})\end{array}$ \\
\hline 1 & 8.3 & 0.27 & 1.5 & 20.4 \\
\hline 2 & 6.4 & 0.25 & 1.4 & 15.7 \\
\hline 3 & 5.4 & 0.18 & 1.1 & 11.9 \\
\hline 4 & 6.7 & 0.14 & 1.3 & 22.5 \\
\hline 5 & 8.2 & $0 . .28$ & 1.4 & 22.5 \\
\hline 6 & 5.4 & 0.17 & 1.1 & 17.1 \\
\hline 7 & 3.9 & 0.13 & 1.1 & 9.2 \\
\hline 8 & 6.5 & 0.24 & 1.4 & 17.1 \\
\hline Plot 1-8 & 6.4 & 0.50 & 3.9 & 8.3 \\
\hline
\end{tabular}

Source: Thapa et al, 2001, Chowdhary and Paudel 2008, updated field data in 2017)

Table 5: Average diameters, minimum and maximum diameter and standard error

\begin{tabular}{|l|l|l|l|l|}
\hline Plot no. & $\begin{array}{l}\text { Av. Diameter } \\
(\mathrm{cm})\end{array}$ & Standard error & $\begin{array}{l}\text { Minimum error } \\
(\mathrm{cm})\end{array}$ & $\begin{array}{l}\text { Maximum } \\
\text { diameter }(\mathrm{cm})\end{array}$ \\
\hline 1 & 3.5 & 0.07 & 2 & 6 \\
\hline 2 & 4.1 & 0.09 & 2 & 6 \\
\hline 3 & 4.2 & 0.08 & 2 & 6 \\
\hline 5 & 3.7 & 0.05 & 2 & 6 \\
\hline 6 & 3.4 & 0.07 & 2 & 6 \\
\hline 7 & 4.0 & 0.06 & 2 & 6 \\
\hline 8 & 4.4 & 0.08 & 2 & 6 \\
\hline Plot 1 to 8 & 3.9 & 0.08 & 2 & 4.4 \\
\hline
\end{tabular}

Thapa et al, 2001 and Chowdhary and Paudel 2008, updated field data in 2017) 
ISSN: 2362-1303 (Paper) | eISSN: 2362-1311 (Online)

JOURNAL OF ADVANCED ACADEMIC RESEARCH (JAAR)

\section{Green and Dry weight of rattan cane}

Green weight and dry weight of rattan cane was estimated in major three community forests of

Kailali and Bardiya district. According to Paudel and Chowdhary (2005) green weight of rattan with leaf sheath is $1.24 \mathrm{~kg}$ per rattan cane height of 6 meter. Weight difference of rattan with and without leaf sheath is $25 \%$. However, oven dry weight of rattan cane is $75.9 \%$ less and air dry weight is 27 to $35 \%$ less (Thapa, Paudel, \& Chowdhary, 2000) and air dry weight is reported also $27.71 \%$ reduction in weight (Chowdhary \& Paudel, 2008). All the Community Forest User Groups sell the dry weight rattan (Table 6).

Table 6: Green and dry weight of rattan

\begin{tabular}{|l|l|l|l|l|}
\hline $\begin{array}{l}\text { Name of } \\
\text { CFUG }\end{array}$ & $\begin{array}{l}\text { Total number of } \\
\text { sampled rattan cane }\end{array}$ & $\begin{array}{l}\text { Green weight } \\
(1.2 \mathrm{Kg} / \text { stem })\end{array}$ & $\begin{array}{l}\text { Oven dry } \\
\text { weight }(75 \%)\end{array}$ & $\begin{array}{l}\text { Dry weight (30\% } \\
\text { reduction) air dry }\end{array}$ \\
\hline Sati & 3956 & 4747.00 & 1187 & 2448 \\
\hline Sarswoti & 3896 & 4675.00 & 1169 & 2805 \\
\hline Shiva & 3892 & 4670.00 & 1168 & 2802 \\
\hline
\end{tabular}

Source :(Thapa et al, 2001, Modified with the Field data 2017)

Yield regulation and estimation of Current Annual Increment (CAI) and Mean Annual Increment (MAI)

\section{Current Annual Increment (CAI)}

Current Annual Increment (CAI) and Mean Annual Increment (MAI) was estimated referring growth of stem in a periodic of time and MAI with the average mean annual increment. The average CAI of rattan of eight CFs is 1.54 meter per year, where minimum 1.40 meter per year and maximum 1.84 meter per year (Table 7).

Table 7: Summary of Current Annual Increment in Eight Community Forests of Kailali and Bardiya districts

\begin{tabular}{|c|c|c|c|c|c|}
\hline \multirow[t]{2}{*}{ District } & \multirow{2}{*}{$\begin{array}{l}\text { Name } \\
\text { CFUG }\end{array}$} & \multicolumn{2}{|c|}{ Length of rattan cane (m.) } & \multirow{2}{*}{$\begin{array}{l}\text { Current Annual } \\
\text { Increment } \\
\text { m/year }\end{array}$} & \multirow[b]{2}{*}{$\begin{array}{l}\text { Standard } \\
\text { deviation }\end{array}$} \\
\hline & & 2 year & 6 years & & \\
\hline Kailali & Sati Karnali & 1.76 & 2.16 & 1.40 & 0.506 \\
\hline \multirow[t]{7}{*}{ Bardiya } & Sarswoti & 2.06 & 2.77 & 1.84 & \\
\hline & Shiva & 1.76 & 2.16 & 1.40 & \\
\hline & Lathahawa & 2.06 & 2.77 & 1.47 & \\
\hline & Khata & 1.76 & 2.25 & 1.47 & \\
\hline & Bhimpur & 1.47 & 1.99 & 1.32 & \\
\hline & Tharu & 2.06 & 2.24 & 1.54 & \\
\hline & Neulapur & 1.76 & 2.08 & 1.32 & \\
\hline \multicolumn{4}{|l|}{ Mean } & 1.47 & \\
\hline
\end{tabular}

Source field inventory 2017 
ISSN: 2362-1303 (Paper) | eISSN: 2362-1311 (Online)

JOURNAL OF ADVANCED ACADEMIC RESEARCH (JAAR)

June 2020

\section{Mean Annual Increment (MAI)}

The mean annual increment (MAI) refers to the average growth per year a tree or stand of trees has exhibited/experienced to a specified age. Diameter of stems was taken above $15.25 \mathrm{~cm}$ from the ground level. Details of rattan forest in various community forests of Kailali and Bardiya are presented in Table 8. The table illustrates that average MAI of Calamus tenuisis $0.150 \mathrm{~cm}$ per year, the MAI of Sati Karnali is $0.146 \mathrm{~cm}$ per year which is 11.28 percent less than Lathahawa $\mathrm{CF}$.

Table 8: Summary of Mean Annual Increment in Eight Community Forests of Kailali and Bardiya districts.

\begin{tabular}{|l|l|l|l|l|}
\hline District & Name of CFUG & $\begin{array}{l}\text { Mean diameter } \\
(\mathrm{cm})\end{array}$ & Year & $\begin{array}{l}\text { Mean Annual Increment } \\
\text { cm/year }\end{array}$ \\
\hline Kailali & Sati Karnali & 0.8780 & 6 & 0.1463 \\
\hline \multirow{5}{*}{ Bardiya } & Sarswoti & 0.9700 & 6 & 0.1618 \\
\cline { 2 - 5 } & Shiva & 0.9390 & 6 & 0.1565 \\
\cline { 2 - 5 } & Lathahawa & 0.9766 & 6 & 0.1628 \\
\cline { 2 - 5 } & Khata & 0.9062 & 6 & 0.1511 \\
\cline { 2 - 5 } & Bhimpur & 0.9030 & 6 & 0.1506 \\
\cline { 2 - 5 } & Tharu & 0.9682 & 6 & 0.1613 \\
\cline { 2 - 5 } & Neulapur & 0.9340 & 6 & 0.1557 \\
\hline \multirow{2}{*}{ Average } & & & & 0.1551 \\
\hline
\end{tabular}

From the Table 7 and 8, it is clear that both CAI and MAI are highest in Lathahawa Community Forest than Sati Karnali Community Forest and Shiva Community Forest. Rattan was not harvested in Bardiya district

\section{Allowable cut of rattan}

Availability and allowable cut of rattan was estimated as approved Forest Operational Plan (FOP) of Sati Karnali, Sarswoti, Lathahawa and Tharu community forests is presented in the Table 9. The FOP is valid for three years from BS 2071. Area of rattan forests are different 157 ha, 3 ha, 4 ha, 19.5 ha and 3.5 ha of Sati Karnali, Shiva, Tharu, Sarswoti and Lathahawa respectively. Regeneration (middle size and small size) was 35 to 38 percent. According to FOP, rattan stocking was 16500 to 25450 per ha and annual cut at the rate of $65 \%$ was 8750 in Sarswoti CF and 15000 per hector in Lathahawa CF and annual allowable cut was prescribed 40 percent in Sarswoti and 25 percent in Lathahawa that equals $3500 \mathrm{~kg}$ and $5750 \mathrm{~kg}$ in Sarswoti and Lathahawa CFs (Table 9). 
ISSN: 2362-1303 (Paper) | eISSN: 2362-1311 (Online)

JOURNAL OF ADVANCED ACADEMIC RESEARCH (JAAR)

June 2020

Table 9: Availability and allowable cut of rattan in Community Forest

\begin{tabular}{|l|l|l|l|l|l|l|}
\hline $\begin{array}{l}\text { Name of } \\
\text { Community } \\
\text { Forest }\end{array}$ & $\begin{array}{l}\text { Area of } \\
\text { rattan } \\
\text { (ha) }\end{array}$ & $\begin{array}{l}\text { Average } \\
\text { weight } \\
\text { (kg/ha) }\end{array}$ & $\begin{array}{l}\text { Rattan per } \\
\text { hector }\end{array}$ & $\begin{array}{l}\text { Growth } \\
\text { rate(kg) }\end{array}$ & $\begin{array}{l}\text { Allowa } \\
\text { ble cut }\end{array}$ & $\begin{array}{l}\text { Total annual } \\
\text { allowable cut/ } \\
\text { ha }\end{array}$ \\
\hline Sati Karnali & 157 & 8811 & 25425 & $8898(38 \%)$ & $65 \%$ & 16525 \\
\hline Shiva & 3 & 3800 & 17280 & $4320(35 \%)$ & $65 \%$ & 11232 \\
\hline Tharu & 4 & 3700 & 16780 & $6040(35 \%)$ & $65 \%$ & 10907 \\
\hline Sarswoti & 19.5 & 3650 & 16500 & $4125(25 \%)$ & $75 \%$ & 12375 \\
\hline Lathahawa & 3.5 & 1500 & 15000 & $3750(25 \%)$ & $75 \%$ & 11250 \\
\hline
\end{tabular}

\section{DISCUSSION}

The germination performance of Calamus tenuis, Calamus acanthospathusand Calamus.leptospadix) showed different result in two different nurseries experimented at tropical and sub-tropical climate. The overall germination was 75.7 per cent in subtropical whereas 30.2 per cent in tropical climate nursery. However, germination of Calamus acanthospathus, Calamus leptospadix and Calamus tenuis was 100 per cent, 64 percent and 42.2 per cent, respectively.Seed germination was taken place from 21 days, the maximum germination was taken between 60 to 80 days, and continued up to 117 days. The result shows that survival per cent was higher of Calamus tenuis up to $4^{\text {th }}$ month in Kailali and then decreased, whereas Calamusacanthospathus less survival percent. Supporting to this statement, Islam, Miah \&Habib(2015) concluded 36.75 per cent average survival in the plantation of Calamus tenuis in Bangladesh.

Mean growth of Calamus tenuis in community forests was 0.85 meter $\mathrm{cm}$ per year. There are various research findings to support this statement. According to research studies and observation carried out in the Philippines the rattan cane grows at the average rate of 0.70 meter per year ( (IIRR, 1992). A similar studies carried out in China by Yang et al (ND) also showed that some medium-diameter species, such as Daemonorops margarita and Calamus simplicifolius, growing fast with annual increment of $1.0-1.5 \mathrm{~m}$ and continue to keep these vigorous trends for 2 to 3 years or more after reaching technical maturation. The research study carried out by Islam et al(2015) in Bangladesh on Calamus tenuis mentions that average growth rate is 1.78 meter per year. Chowdhary and Paudel (2008) also concluded that growth of Calamus tenuis is up to 2.5 meter per year if they are climbed on trees. The study carried out in Bangladesh shows that the maximum stem length was recorded $21.15 \mathrm{~m}$ (Islam S. A., Miah, Habib, \& Rasul, 2015). Calamus tenuis is a clumpy palm producing 3-7 rhizomes in one year and increase up to 25 rhizomes in 3-4 years period. There are 15 to 25 percent immature culms in 
a clump, and number of clumps are 200 to 500 in per hectare. Average number of rattan cane was 4 in per square meter of each community forest. Mean length and mean diameter was measured 5.47 meter $9.23 \mathrm{~mm}$. The estimation shows that there is no more different in growing stock in per $\mathrm{m}^{2}$ in them.

Current Annual Increment (CAI) and Mean Annual Increment (MAI) was estimated referring growth of stem in a time period and MAI with the average mean annual increment. The average CAI is 1.54 meter per year, where minimum 1.40 meter per year and maximum 1.84 meter per year. The mean annual increment (MAI) refers to the average growth per year a tree or stand of trees has exhibited/experienced to a specified age. Diameter of stems was taken above $15.25 \mathrm{~cm}$ from the ground level. The average MAI of Calamus tenuis of are $0.1514 \mathrm{~cm}$ per year.

Weight difference of rattan with and without leaf sheath is 25 per cent. However, oven dry weight of rattan cane is 75.9 per cent less and air dry weight is 27 to 35 per cent less (Thapa, Paudel, \& Chowdhary, 2000) and air dry weight is reported also $27.71 \%$ reduction in weight (Chowdhary \& Paudel, 2008).

Availability and allowable cut of rattan was estimated as approved Forest Operational Plan (FOP) of Sati Karnali, Sarswoti, Lathahawa and Tharu community. According to FOP, rattan stocking was 16,500 to 25,425 per ha and followed annual cut was $65 \%$ to $75 \%$. Rotation year of Calamus tenuis has been estimated six years in Nepal that looks justified by the Dransfield (1977) that small diameter rattan can be harvested at as early six years of planting. However, Saharia and Sen (1990) recommended 12 years of rotation year of Calamus tenuis. Concerning to retaining of rattan stems in the harvesting blocks is not standardized yet. In East Kalimanta, only 10-20\% of the stems in a cluster are harvested at a time ( (Peluso, 1986).

After the implementation of Rattan Management Plan, significant improvement was noticed in all the rattan forests, those adopted it. CFUGs were sensitized to accrue benefit from other sources rather than commercial culms. They were derivatives such as leaf sheath, fruits, NTFPs and sale of seedlings produced in the nursery. For example of Sati Karnali Community Forest User Group showed that benefit increased 5 to 6 times (i.e. before RMP benefit was Rs 0.2 million which was reached up to 4 to5 million (Paudel \& Chowdhary, 2005).

\section{CONCLUSIONS}

Estimation of growing stock helps to plan for the volume of products for commercial uses. Sustainable management of forest requires inventory of growing stock, quantity of annual harvesting, percent of regeneration, sapling and mature stocks, difference between green weight and dry weight, commercial length and diameter of rattan. The estimation of growing stock ensures commercial volume forest products per year. This study explored the growth pattern of rattan cane in 21 community forests of Kailali and Bardiya districts.

The measurement of growing stock was based on the sampling. Although the rattan cane was distributed in many community forests, growing stocks were still to be incorporated in the Forest Operational Plan. The growing stock was crucial for preparation of Initial Environmental 
ISSN: 2362-1303 (Paper) | eISSN: 2362-1311 (Online)

JOURNAL OF ADVANCED ACADEMIC RESEARCH (JAAR)

June 2020

Examination and Environmental Impact Assessment reports, and growing stock needs to be incorporated in the FOP.

\section{ACKNOWLEDGEMENTS}

I express my deep gratitude and thanks to Community Forest User Groups for their cooperation during the field work, Chairperson Sati Karnali Community Forest User Group, Mr. Sharma Chaudhary and his staff members, Mr. Mani Ram Dhungana, Devi Ram Bhandari, Min Bahadur Thakula, Chairperson of Sarswoti CFUG Rajapur, Bardiya Mr. Sharma Chaudhary, secretary, Ratrani Chaudhary, and their team members, Moti Ram Chaudhary, the Chairperson of Lathahawa CFUG, Rajapur, Bardiya, Dron Raj Sharma, AFO of District Forest Office, Bardiya. I thank to all the rattan cane processing industries of Nepal for providing me invaluable information during the data collection.

\section{REFERENCES}

Barry, D., Campbell, J., Fahn, J., \& Pradhan, U. (2003, April 18). Achieving significant impact at scale:Reflections on the challenges for global community forestry. Rural Livelihoods, Forests and Biodiversity.

Chapman, H. (1921). Forest Mensuration, Second Edition. New York: Willey and Sons Inc.

Chowdhary, C. L., \& Paudel, S. (2008). Rattan Cultivation, Management and Development Initiatives in Nepal. Kathmandu: Kabita and Sunita.

Dhakal, D. (2016). Value Chain Analysis of Rattan: A case study of Bardiya Distict. Bhaktapur: Department of Environmental Science, Khwopa College.

Dransfield, J., \& Manokaran, N. (1993). Plant Resources of South East Asia. PROSEA, 6.

Dransfild, J. (1977). Calamus caesium and Calamus trachycoleus compared. Singapore: Gardens Bulletin.

Henderson, C. M., \& Andrew. (2014). Systematics, Ecology and Managmeent of Rattans in Cambodia, Laos and Vietnam:The biological bases of sustainable use. New York: WWF, The NeW York Botanical Garden.

Husch, B., Miller, C., \& Beers, T. (1982). Forest Mensuration. New York: Wiley.

IIRR. (1992). Trees and Their Management, 195 P. Retrieved April 14, 2020, from Community Development Library: www.nzdl.org/gsdlmod

Iqbal, M. (1993). International Trade in Non-Wood Forest Products An Overview. FAO Working paper, 93(11).

Islam, S. A., Miah, M. A., Habib, M. A., \& Rasul, M. G. (2015). Growth performance of Calamus tenuis Roxb (jalibet) inthe coastal homestead of Banlgadesh. Journal of Bioscience and Agriculture Research, 4(2), 74-79.

Islam, S., Miah, M., \& Habib, M. a. (2015). Growth performance of Calamus tenuis Roxb (Jali bet) in the coastal Homesteads of Bangladesh. Retrieved April 14, 2020, from Journal of Bioscience and Agriculture Research 04(02):74-79: www.researchgate.net/publication 
ISSN: 2362-1303 (Paper) | eISSN: 2362-1311 (Online)

K.Sengdala, \& Evans, T. (2002). The adoption of rattan cultivation for edible shoot production in Lao PDR and Thailand - From non timber forest product to cash crop. Economic Botany, $56(2)$.

Manokaran, N. (1990). The State of the Rattan and Bamboo Trade. Research Institute Center (RIC).

Olsen, C. (1997). Commercial Non-Timber Forestry in Central Nepal: Emerging Themes and Priorities. Royal Veterinary and Agriculture University. Copenhagen, Denmark: Royal Veterinary and Agriculture University.

Pabuayon, I. (2000). Addressing rattan technology needs for Asia. Kualalumpur, Malasia. XXI IUFRO World Congress 2000. Kualalumpur, Malasia.

Paudel, S., \& Chowdhary, C. (2005). Managing Rattan as a common property: a case study of community rattan management in Nepal. Bamboo and Rattan, 4(1), 81-91.

Peluso, N. (1986). Rattan industries in East Kalimantan, Indonesia. FAO Policy and Planning Service. Rome: FAO.

Saharia, U. a. (1990). Growth and yeild of cane (Calamus tenuis, Roxb.) in Asam. Indian Forester, 116:303-305.

Sastry, C. (2002). Rattan current research and prospect for conservation and sustainable development. Rattan the 21st Century-An Outlook(14), pp. 237-244.

Siebert, S. (2002). Harvesting Wild Rattans:Opportunites, Constraints and Monitoring Methods. In J. Dransfield, F. O. Tesero, \& N. Manokaran (Ed.), Rattan: Current Research Issues and Prospects for Conservation and Sustainable Development.14, pp. 227-236. Rome: Food and Agriculture Organization of the United Nations.

Sukla, D. (2015). Growth and Development of Valuable Threatend Climber Species Calamus tenuis Roxb in District Meerut,( U.P.) India. International Journal of Science and Research (IJSR), 4(5), 1916-1920.

Sunderland, T., \& Dranfield, J. (2000). Species Profile Rattan (Palmae: Calamoidae). In F. T. John Dransfield (Ed.), Rattan Current Research Issues and Prospects for Conservation and Sustainable Development.1, pp. 9-22. Rome: INBAR.

Thapa, H., Paudel, S., \& Chowdhary, C. (2000). Identification, Validation and In-situ Conservation of Rattans in Nepal. Department of Forest Research and Survey. Kathmandu, Nepal: International Network for Bamboo and Rattan (INBAR).

Vantomme, P. (2003). Growing Imbalance between Supply and Demand of Rattan? Bamboo and Rattan, 2(4), 407-415.

Yang Jinchang, X. H. (ND). An overview of rattan plantation management. Retrieved April 14, 2020, from http://www.fao.org/3/XII/0348-B1.htm\#fn1 